\title{
Economic Assessment of Optimization of Machine-Building Production on the Basis of Restructuring Outsourcing Taking Into Account the Cyclical Nature of Economic Development
}

\author{
Il'nur Ildusovich Farkhoutdinov ${ }^{1} \&$ Aleksei Gennadevich Isavnin ${ }^{1}$ \\ ${ }^{1}$ Economic Department, Kazan Federal University, Russia \\ Correspondence: Il'nur Ildusovich Farkhoutdinov, Economic Department, Kazan Federal University, Russia. Tel: \\ 8-960-070-1168. E-mail: ilnour1986@inbox.ru
}

Received: October 9, 2020

Accepted: December 14, 2020

Online Published: January 1, 2021

doi:10.5430/ijfr.v12n1p286

URL: https://doi.org/10.5430/ijfr.v12n1p286

\begin{abstract}
Nowadays using outsourcing and models of sourcing's maneuver, becomes as one of the most leading tools for optimizing domestic engineering production. Many entrepreneurs reject outsourcing because they think that outsourcing will incur additional costs. However, they make mistakes in calculating the value of missed opportunities because they spend so much time on hard, energy-intensive work that it would be better to leave that to others. Therefore, outsourcing may be toxic to some businesses, and the same activity can be very successful if done within the organization. Outsourcing simplifies many tasks and is profitable for organizations and companies, but only if the conditions are carefully considered, and security points are observed. Every business, large or small, needs to outsource some of its activities, whether it hires an individual or a team to do their work at the company or do it elsewhere. In this paper, the authors consider the optimization of domestic machine-building enterprises through the use of restructuring production outsourcing. An approach to the economic evaluation of the machine-building production optimization based on the restructuring outsourcing, taking into account the cyclical nature of economic development, is developed.
\end{abstract}

Keywords: restructuring outsourcing, production optimization, cyclical economic development, economic effect, production capacity, break-even point

\section{Introduction}

Outsourcing means entrusting some of the company's affairs to another person, team or organization under a specific contract. It often happens that a company or set of time does not have the necessary budget, equipment, equipment or skills to do something, so they delegate that particular action to another organization to do it. In such circumstances, outsourcing has been done. Usually, things other than the core business of the company are outsourced. It does not matter where the work is done, in your company or outside of the company, however, when a person or team from another organization does something that you do not have the time or skill to do, outsourcing is done (Liu et al., 2017; Zhang et al., 2018). As human knowledge in the present age is growing daily and even momentarily, and new technologies are constantly changing and evolving in our world, so the needs of society or the desires of customers of any business are also changing. Everyone wants to get the best service, but the reality is that no matter how big, strong, and up-to-date a company is, it still can't make progress on a daily basis because it is too costly. But this is not the end of the matter, as outsourcing has opened the way for any business or business to thrive and keep up with technology. Outsourcing allows you to use the facilities, skills and resources of another company that has the most up-to-date equipment and methods to do the work and pay only the cost of doing the work, nothing else! Outsourcing allows us to use the knowledge, equipment and resources of other organizations when needed, but to avoid the cost of formal hiring. To compete in the global arena, you need to keep up with the standards and technologies of the day. This will be possible through outsourcing (Gerbl et al., 2016; Smith \& Smith, 2017; Errighi et al., 2016; Rekik et al., 2016: Bykova et al, 2019).

Many believe that the main reason for outsourcing is to reduce costs. This belief is true to some extent, but this is not all that persuades organizations to outsource! There are countless reasons to outsource, but some of the most important are: reduce investment costs, focus on the main activities of the organization, acquire new technologies at 
low cost, use the skills and knowledge of others without being formally hired, save time, higher quality, flexibility, take advantage of fleeting opportunities, Reducing the volume of activity of the company's employees in special circumstances etc. (Nacer et al., 2019; Krysińska et al., 2018).

The term outsourcing was first coined in 1989 to describe Kodak's decision to outsource its information technology business to an IBM subsidiary as a technology and business strategy. It used to be, however, that even before that, many companies did not do all their own work and outsourced less competitive activities to outsourced contractors. In fact, it may be said that the idea of outsourcing first appeared in Adam Smith's book "The Wealth of Nations [1776]", in which Adam Smith states: The family never tries to make something at home that can cost them more than buying it. On the other hand, outsourcing has been a kind of build-purchase decision. The oldest studies on outsourcing are also under this heading. The economic issues in this field are then modelled using transaction cost theory and the theoretical basis of outsourcing in small businesses, which is often referred to as "transaction cost economics". It should be noted that although most of the existing literature on outsourcing deals with large companies, most companies are relatively small. Therefore, it is important to see how small and medium-sized businesses deal with outsourcing. In fact, in this article, we examine the outsourcing of small businesses. Previous studies of SME collaboration strategies have focused on relationships in which SMEs provide some of the elements or services to the larger firm. Therefore, there are few statistics about outsourcing in these businesses or outsourcing in small businesses (Lacity et al., 2016; Boukadi et al., 2019: Kireeva et al, 2019).

By the third millennium, most sectors of the industry are facing tense and acute conditions, both in the market and within the company. Customers, on the other hand, impose more restrictions on their loyalty to their initial relationships with vendors; Previously, customers mainly focused on low total cost, high quality and good delivery performance. At present, they expect short product life cycle and product entry time, innovation, and custom product development; On the other hand, companies and their suppliers are experiencing the emergence of a global economy as well as rapidly changing markets (Zandi et al., 2019). At the same time, the complexity of products and technologies is increasing, and their ability to work is expanding. Due to such internal and external conditions, companies must be able to change their organization, operations, product portfolio, customer segmentation, and quickly, efficiently, and on a consistent basis. This requires a new approach to the strategic planning process and sometimes the need to outsource to small businesses (Kanniappan \& Selvakumar, 2020; Mukucha et al., 2020).

As a managerial experience, outsourcing has been around for almost 200 years, but over the past 15 years, due to strategic issues as well as costs, this method has been developed as a managerial and public activity. In fact, organizations no longer try to do all the necessary activities themselves. Each organization retains one or two activities that are key to that organization and thereby create value for customers beyond competitors, and the rest of the activities through other businesses in which activities are key capabilities. They are doing, in fact, outsourcing to small businesses is expanding today. The task of handing over tasks to outside forces in developed countries has been going on for a long time. Meanwhile, developed countries in East Asia have achieved significant success in reducing production and service costs. These countries include India and China. But the approach of outsourcing or sourcing outside the organization is a new approach for our country with a short history. Perhaps the belief is not yet institutionalized among the managers and officials of our organizations that this method can increase productivity, reduce costs, and attract more employee participation (Somjai, 2017). Figure 1 shows the man reasons for business process outsourcing.

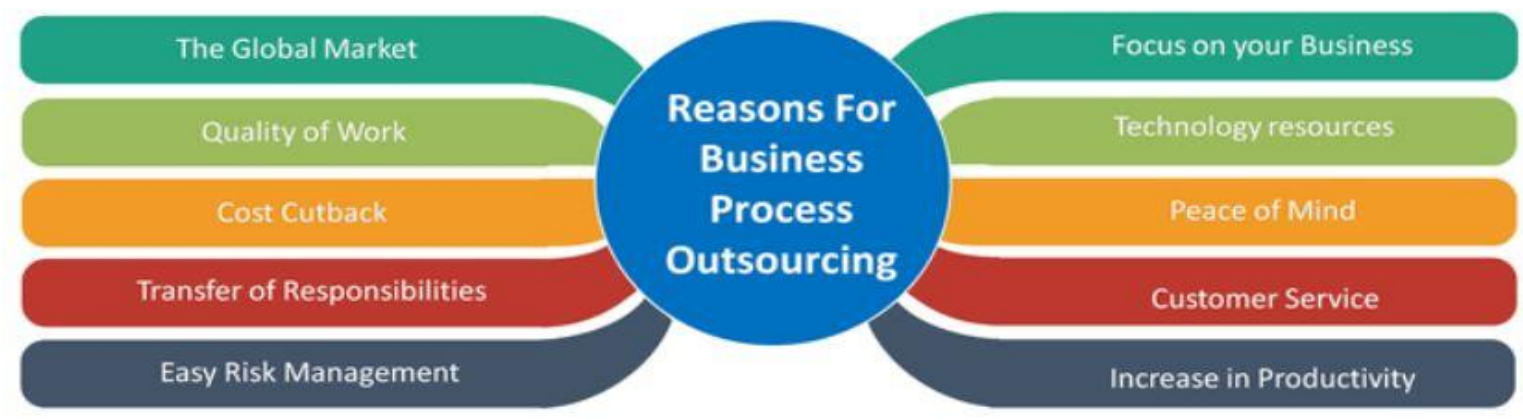

Figure 1. Reasons for business process outsourcing 
In outsourcing, according to previous studies, almost any type of activity is outsourced in any sector, but initial studies and expert observations outsource some activities in some sectors. The major operational tasks that are outsourced to small businesses are typically related to accounting, maintenance, security, promotion, and warehousing. Also, the more difficult and complex the use of outsourcing becomes, the more organizations outsource responsibility for their business processes in addition to the activities themselves (Umukoro et al., 2020).

The use of restructuring models of sourcing, for example, such as outsourcing and models of sourcing's maneuver, is one of the most popular tools for optimizing domestic engineering production. The appeal to these models is due to the fact that restructuring sourcing, when properly applied, can significantly increase the flexibility of production, in particular, increase the production capacity of the enterprise and significantly reduce the value of the break-even point. These advantages, acquired by companies when optimizing production based on sourcing models, allow them to function more competitively in conditions of cyclical economic development. However, not all domestic machine-building enterprises manage to properly restructure their business. In this regard, the development of an approach to the economic assessment of production optimization based on outsourcing, taking into account the cyclical nature of economic development, is a promising scientific direction.

The purpose of this work is to develop a method for justifying the economic effect of utilizing restructuring outsourcing in a machine-building enterprise, taking into account the cyclical nature of economic development.

\section{Methods}

Outsourcing can be divided into two general categories according to the location and nature of the work, and subcategories can be considered for each category:

- Outsourcing by location: You can outsource your company, and everything inside is done by an outsider, team or organization, or you can outsource your work to a group outside your organization. There are some things that need to be done inside your collection, and there is no other way, but there are many things that can be done remotely or worked on elsewhere.

- Outsourcing according to the nature of the work: Outsourced operations can be defined as a project or a process-oriented approach. There are some things that are defined as a simple project because they have a definite result and expectations are determined in advance. But some things require error and trial, and the process is better centred. The contract can be adjusted for the return to be determined at any given time.

But in general, there are four general ways to outsource:

- Project outsourcing: Project outsourcing comes with the great promise of cost savings. Companies outsource projects and get things done according to their needs. It does not matter if the project is physical or done on the web. When we talk about the project, it means temporary employment.

- Professional outsourcing: In this method of outsourcing, you delegate almost everything and tasks to a specific person or team that has specific expertise, and you have nothing to do with the way the project is done. They are obliged to deliver the desired result within the specified time and receive the agreed amount in return. This method of outsourcing has no boundaries and can be used to do a physical job or for a marketing process with anything else. For example, building a road or auditing a company.

- Information Technology Outsourcing: Outsourcing is more entrenched in technology and the Internet. Large technology companies can outsource their large projects to other individuals or companies. Because most things can be done on the Internet, information technology outsourcing is one of the most popular. These companies can hire people and work remotely, or define projects and finally get the job done. It has no boundaries, and freelancing is one of the sub-branches of information technology outsourcing.

- Outsourcing of manufacturing or production: This outsourcing method allows you to hire a company to produce the goods you need. So, you hire a factory or company to produce the goods you need, what many large companies do. For example, smartphone companies are hiring companies in China to make their products. This is done to save on production costs and labour.

The cyclical nature of economic development is an integral part of the capitalist economic model. To date, the following definitions of the concept of "economic cycle" are found in the scientific literature:

1. The economic cycle is a type of fluctuation in the aggregate economic activity of nations organizing their economic activities in most cases in the form of private enterprise. The cycle consists of a recovery stage, which can be seen simultaneously in the main types of economic activity, in its place comes the recession stage, characterized by a reduction in production, leading to depression, and then to the recovery stage, which results in a recovery in the 
next cycle; the change in the stages of the cycle can be considered repeated, but not necessarily periodic (Burns \& Mitchell, 1946).

2. The economic cycle is the fluctuations in the economic activity of the national economy and the world economy, manifested in a change in the phases of ups and downs (Orlova, 2015).

3. The economic cycle is a stream quantitatively measurable process that does not have a trend component in its basis, as a market element cyclical component of economic dynamics (Rumyantseva, 2012).

In the entire history of economic thought development, many prominent economists have tried to unravel the causes of recurring crises. Table 1 presents some approaches to the study of the causes of the cyclical fluctuations in a market economy and their authors.

Table 1. Theories of economic cycles and their authors

\begin{tabular}{|c|c|c|c|}
\hline № & Theory name & $\begin{array}{l}\text { The author of } \\
\text { the theory }\end{array}$ & A brief description of the theory \\
\hline 1. & $\begin{array}{l}\text { Theory of industrial } \\
\text { cycles }\end{array}$ & $\begin{array}{l}\text { Karl Heinrich } \\
\quad \text { Marx }\end{array}$ & $\begin{array}{l}\text { Economic crises are generated by the main contradiction of } \\
\text { capitalism - the contradiction between the social nature of } \\
\text { production and the private capitalist way of appropriating the } \\
\text { results of this production. }\end{array}$ \\
\hline 2. & Monetary theory & $\begin{array}{l}\text { Hawthry R., } \\
\text { Fisher I. }\end{array}$ & $\begin{array}{l}\text { Economic crises arise as a result of violations in the field of } \\
\text { monetary supply and demand. }\end{array}$ \\
\hline 3. & Keynesian theory & $\begin{array}{l}\text { John Maynard } \\
\text { Keynes }\end{array}$ & $\begin{array}{l}\text { Economic cycles are the result of the interaction between the } \\
\text { movement of national income, consumption and the } \\
\text { accumulation of capital. In accordance with this theory, the } \\
\text { cycle begins to take shape during a period of dynamic growth in } \\
\text { demand, which, in turn, is determined by consumption and } \\
\text { investment. }\end{array}$ \\
\hline 4. & $\begin{array}{l}\text { The theory of } \\
\text { underconsumption }\end{array}$ & Sismondi J. & $\begin{array}{l}\text { Depression is caused by the fact that too much of current } \\
\text { income is saved and too little is spent on consumer goods. It is } \\
\text { voluntary savings made by individuals and companies that upset } \\
\text { the balance between production and sales. }\end{array}$ \\
\hline
\end{tabular}

Source: Tupchienko V.A., Krivtsova M.K. Key theories of the economic cycle // Financial analytics: problems and solutions. 2014. No3.

Next, we consider approaches to the classification of economic cycles that are found today in the scientific literature. In particular, the following types of economic cycles are distinguished:

1. Duration and frequency (Zychenko, 2013):
a. Kitchin's short-term cycles;
b. Medium-term cycles of the Juglar;
c. Blacksmith rhythms;
d. Long waves of Kondratiev;
e. Forrester cycles
f. Toffler cycles

2. To identify the nature of the causes of economic cycles (Zychenko, 2013):
a. Endogenous cycles;
b. Exogenous cycles

3. by industry affiliation (Baranov, 2014):

a. Oil cycles; 
b. Food cycles;

c. Energy cycles;

d. Raw material cycles;

e. Environmental cycles;

f. Currency cycles.

Despite the variety of approaches presented in the academic literature to the study of the causes of the cyclical fluctuations in a market economy and the classification of economic cycles, all business cycles consist of phases (see Figure 2) and are characterized by indicators such as "oscillation amplitude" and "cycle duration".

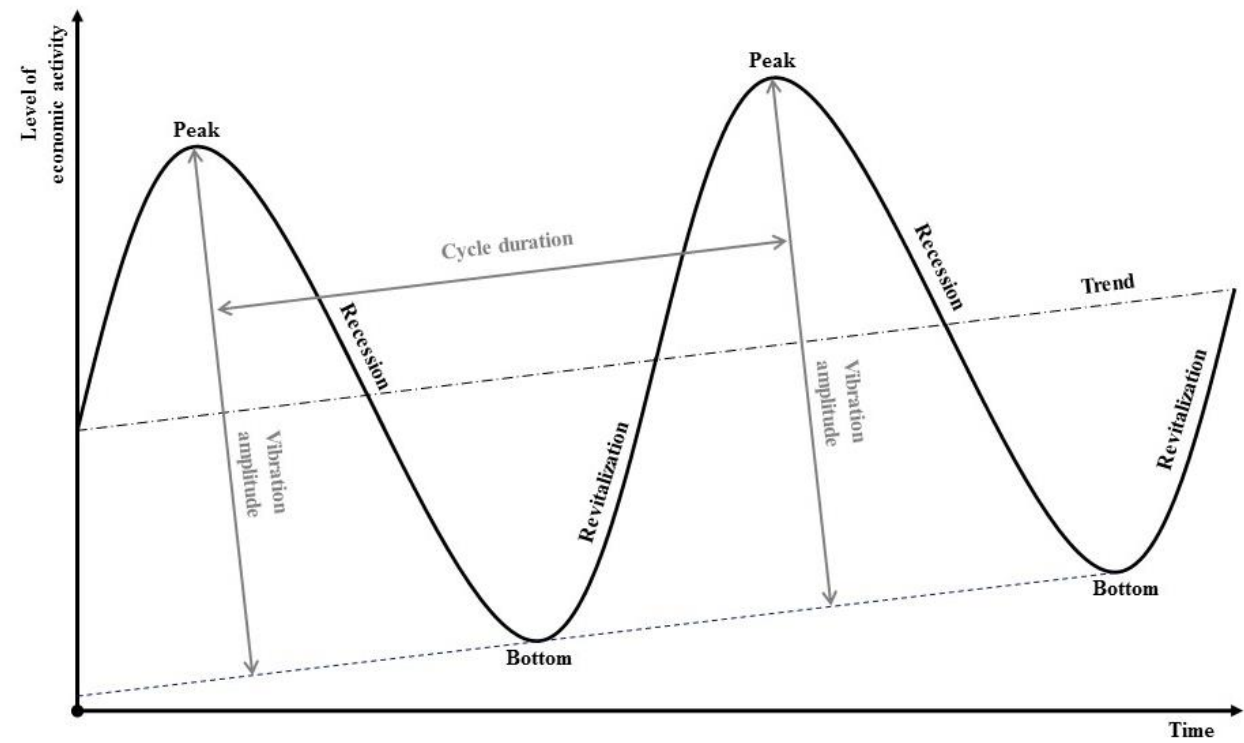

Figure 2. Business cycle phases

Source: compiled by the authors

Note: most often in the economic literature the term "amplitude of oscillations" refers to the difference between the peak and the bottom of the cycle, and in the technical literature, in particular, if we are talking about the theory of oscillations, the maximum value of the change in the variable from the average value, that is, expressed economic language, the difference between the peak or bottom of the cycle and the trend.

\section{Restructuring outsourcing and business cycles}

The use by large engineering enterprises of restructuring outsourcing, the essence of which is that the company sells non-core assets to other firms and interacts with them as part of outsourcing (Isavnin \& Farkhoutdinov, 2013) or displays these assets in a subsidiary or joint venture (Kotlyarov, 2012) is a fairly common phenomenon in Russia. In particular, one can cite such examples as optimization of the production facilities of company "KAMAZ", when the manufacturer abandoned its own uncompetitive automotive components in favour of using American and German ones (Isavnin \& Farkhoutdinov, 2012) and restructuring the business of the company "Irbit Motorcycle Plant". In the article Rybina S.I. "The use of outsourcing to improve the efficiency of the enterprise: foreign experience, Russian practice" presents a list of Russian industrial companies that have widely used restructuring outsourcing (Rybina, 2012).

It should be noted that restructuring outsourcing has proven itself as a tool to increase the firm's resistance to negative external factors in the USA and Canada; in particular, the American automotive industry is a striking example (Isavnin \& Farkhoutdinov, 2012). Table 2 shows some examples of outsourcing applications by the American automotive industry. 
Table 2. Application of outsourcing in the American automotive industry

\begin{tabular}{lccl}
\hline № & Company & Applicable component & \multicolumn{1}{c}{ Component provider } \\
\hline 1. & Freightliner Trucks & Engine & Detroit Diesel Corporation \\
\cline { 3 - 3 } & & & Cummins Inc. \\
\hline \multirow{2}{*}{2.} & Peterbilt Motors Company & Transmission & Paccar Inc. \\
\cline { 3 - 3 } & & & Eaton Corporation \\
\cline { 3 - 3 } & & & Allison Transmission \\
\hline
\end{tabular}

Source: Compiled by the authors based on information provided on the official websites of companies "Freightliner Trucks" and "Peterbilt Motors".

Also, restructuring outsourcing, in addition to reducing the breakeven level of the company, can increase the production capacity of the enterprise, and this advantage is due to the fact that, on the one hand, outsourcing can eliminate the so-called bottlenecks of production (Isavnin \& Farkhoutdinov, 2012), and on the other hand, a company can use the power of an outsourcer (outsourcers) (http://www.mirkin.ru).

Thus, the use of restructuring outsourcing by large machine-building enterprises makes it possible to increase production flexibility and function more competitively in the conditions of economic cycles.

Next, we consider the main assumptions made when developing a method for substantiating the economic effect of restructuring outsourcing, taking into account the cyclical nature of economic development.

\section{Results and Discussion}

In this paper, we consider the abstract market of some engineering products, the cyclical nature of which is described by a sinusoid (1).

$$
v=f_{1}(t)=v_{m}+a * \sin (b * t),
$$

Where $v$ - The value offset of the market volume from the position of the trend; $v_{m}$ - The position of the trend; $a-$ The difference between the peak or bottom of the cycle and the trend; $b$ - The oscillation frequency; $t$ - Time.

A graphical interpretation of the market in question is presented in Figure 3.

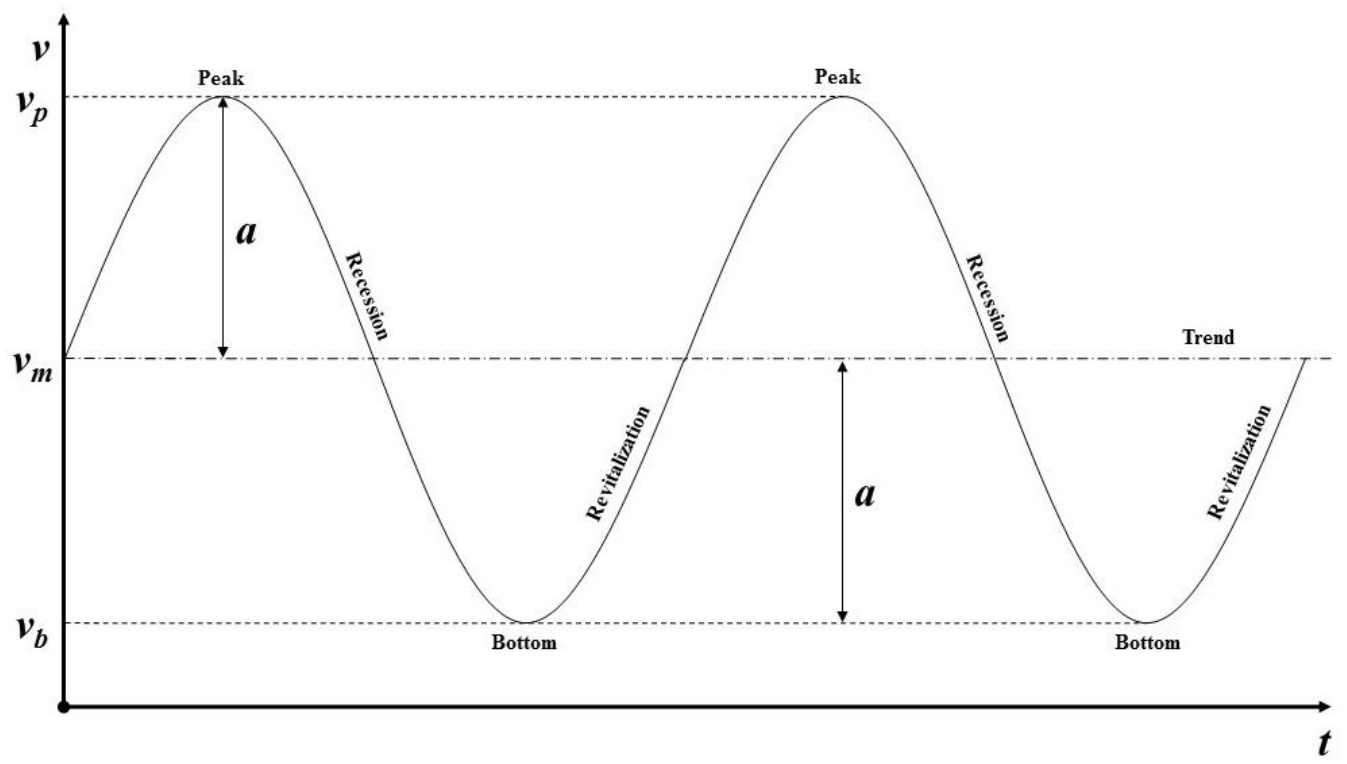

Figure 3. Graphic interpretation of the abstract market in question

Source: Compiled by the authors. 
Figure 2 shows that at the peak of the economic cycle, the market capacity is $v_{p}$, and at the bottom of the cycle $-v_{b}$. Suppose that in this market there is a fixed $n$ number of firms and each firm has its own fixed market share $\alpha_{i}$, where $i=\overline{1, n}$. Then, at the peak of the economic cycle, the $i$ company will be able to sell no more than $\alpha_{i} * v_{p}$ units of engineering products on the market, and at the bottom of the cycle no more than $\alpha_{i} * v_{b}$.

Since the object of the study is a firm, we consider a certain $i$-th firm that needs to optimize production through the use of restructuring outsourcing, that is, this firm has problems (see expression (2)).

$$
\left\{\begin{array}{l}
c_{i}<\alpha_{i} * v_{p} \\
l_{i}>\alpha_{i} * v_{b}
\end{array}\right.
$$

Where $c_{i}$ - the production capacity of the $i$-th company; $l_{i}$ - breakeven level of the $i$-th company.

Based on these assumptions, we model a scenario in which the use of restructuring outsourcing eliminates the problems of the company, and based on this we propose a method for assessing the economic effect of this optimization.

\section{Justification of the economic effect}

A graphical interpretation of the firm in question, unable to meet the increased demand in the interval $\left(c_{i}, \alpha_{i} * v_{p}\right]$ and generating losses at $\left[\alpha_{i} * v_{b}, l_{i}\right)$ Is presented in Figure 4.

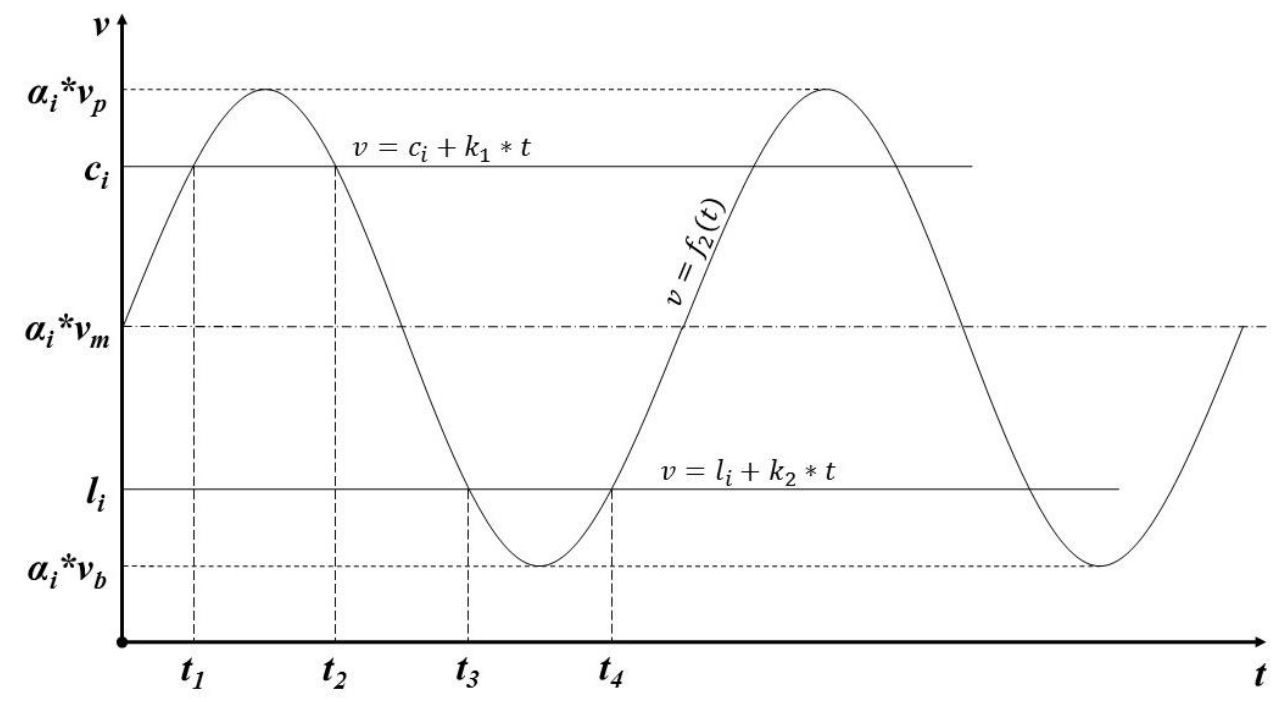

Figure 4. Graphic interpretation of the firm in question

Source: compiled by the authors

Note 1: $v=f_{2}(t)$ - the function of the maximum volume of demand for engineering products manufactured by the company; $v=c_{i}+k_{1} * t-$ the function of the production capacity of the company; $v=l_{i}+k_{2} * t-$ the function of the company breakeven level.

Note 2: $k_{1}=k_{2}=0$.

Obviously, the company is motivated to optimize its own production, since increasing production capacity to $\alpha_{i} * v_{p}$ allows, firstly, to get additional profit, and secondly, to stably maintain a given market share at each phase of the economic cycle. Lowering the breakeven point to $\alpha_{i} * v_{b}$ increases the enterprise's resistance to downturns in business activity.

An economic evaluation of the optimization of a machine-building enterprise through the use of restructuring outsourcing is carried out using the formula (3). 


$$
\left\{\begin{array}{l}
E_{1}=\int_{t_{1}}^{t_{2}}\left(f_{2}(t)\right) d t-c_{i} *\left(t_{2}-t_{1}\right) \\
E_{2}=l_{i} *\left(t_{4}-t_{3}\right)-\int_{t_{3}}^{t_{4}}\left(f_{2}(t)\right) d t
\end{array},\right.
$$

Where $E_{1}$ - economic effect of the utilizing outsourcing, characterized by an increase in the production capacity of the enterprise; $E_{2}$ - economic effect of the use of outsourcing, characterized by a decrease in the breakeven level of the enterprise.

It can be seen from expression (3) that the proposed economic assessment is limited by the duration of one cycle; therefore, taking into account the fact that the abstract market and company are considered in this work, we supplement formula (3) with a variable equal to the number of economic cycles that enterprises have overcome since completion restructuring (see expression (4)).

$$
\left\{\begin{array}{l}
E_{1}=x *\left(\int_{t_{1}}^{t_{2}}\left(f_{2}(t)\right) d t-c_{i} *\left(t_{2}-t_{1}\right)\right) \\
E_{2}=x *\left(l_{i} *\left(t_{4}-t_{3}\right)-\int_{t_{3}}^{t_{4}}\left(f_{2}(t)\right) d t\right)
\end{array},\right.
$$

Where $x$ - The number of economic cycles that the firm has overcome since the completion of the restructuring.

\section{Summary}

Outsourcing has many advantages, some of which we will discuss in the following:

1. Cost reduction and budget management: Although all managers believe they know the best way to manage their budget, outsourcing does it better than anyone else. Suppose you want to start internet marketing for your business if you want to hire a professional team, there are no obstacles, but you should consider a separate office for them within the organization, desks and chairs, work equipment such as computers etc. Provide for them, give them a fixed salary, incur additional costs such as maintenance, catering, etc., from the company's budget. But what does outsourcing do with these costs? When you outsource the marketing of the company because it is done online, you will not need the necessary space and equipment to do this, and they provide the necessary tools themselves. You do not have to pay for the time the team members are browsing the web or chatting on social media; they only get paid for the work done and predetermined! Employees of a company are usually not satisfied with their salaries and use insurance and other benefits of the company, which outsourcing eliminates all these costs. In this way, the costs of doing things are greatly reduced, and the company's budget can be better managed.

2. Focus on the main goals of the company: A company should not be expected to have as many quality and well-managed departments as all its core services. Companies usually focus on their core goals but will run into problems if they fail to properly manage and manage ancillary processes. When a company grows, the scope of small and large tasks also increases, and on the other hand, the company's human resources try harder to pursue the main goals and ignore the details. Eventually, it causes weaknesses in the company that sometimes have detrimental consequences. But if many side tasks are outsourced, the organization can focus on the main goal of the company without worry. Suppose you want to improve the security network of the organization. If you ask your employees to do this, their main tasks will undoubtedly remain unfulfilled. That's why outsourcing makes companies never lose focus on the basics.

3. Access to skilled and specialized staff: Outsourcing a project means accessing an expert person, team or organization. Regardless of the cost, it is usually when a project is outsourced that the company itself does not have the skills or time to do it! In such cases, outsourcing can be a daunting task. This means discovering better solutions and using more skills. Such teams, because they have dealt with similar projects before, undoubtedly choose the best way to do the job.

4. Increase the level of knowledge of the company's employees: Sometimes it happens that the company's specialized staff cannot cope with work that is in their area of expertise, that is, they do not have the necessary skills. In such a time, instead of hiring a new force, it can be shown with a double arrow. With outsourcing, things get trickier, and this is where the true potential of the project comes in. They can increase their knowledge and manage and execute the same. Outsourcing can increase the knowledge of the collection and achieve more quality.

5. Saving time: The element of time is more valuable than it is ignored. Saving time is a good reason to 
outsource. It does not matter how big or small your project is. When you outsource it to another company, it will be done in the fastest time, because they get paid for doing a certain thing and try to get it done in the fastest time. On the other hand, because this is their specialty, so they have all the necessary tools and solutions, saving time can be very profitable.

6. Customer and technology flexibility: It has been said before that technology and the needs of customers are changing day by day, and it is not possible to incur high costs to keep up with them. But outsourcing comes with the great promise of cost savings. The team of people working in your company have almost limited resources, which can cause the process to be delayed or not done properly at all. This means that the team or organization that accepts your outsourcing project has access to the latest technologies and more resources. They have better equipment and therefore, more flexibility in the project. When a customer sees such quality and flexibility in your company, they will definitely trust your company's management style.

In this paper, the authors consider the optimization of domestic machine-building enterprises through the use of restructuring production outsourcing. An approach to the economic evaluation of the machine-building production optimization based on the restructuring outsourcing, taking into account the cyclical nature of economic development, is developed. The proposed approach in the current study to the economic optimization evaluation of a machine-building enterprise through the application of restructuring production outsourcing is based on a sufficiently large number of assumptions. However, the developed method is of scientific interest due to the fact that further research in this area will be related to expanding the boundaries of assumptions. In particular, for example, suppose that each economic cycle is individual, and then the economic assessment of optimization will be carried out using the formula (5).

$$
\left\{\begin{array}{l}
E_{1}=\sum_{j=1}^{x}\left(\int_{t_{1}}^{t_{2}}\left(f_{2}(t)\right) d t-c_{i} *\left(t_{2}-t_{1}\right)\right){ }_{j} \\
E_{2}=\sum_{j=1}^{x}\left(l_{i} *\left(t_{4}-t_{3}\right)-\int_{t_{3}}^{t_{4}}\left(f_{2}(t)\right) d t\right)_{j}
\end{array}\right.
$$

\section{Conclusions}

Arguing regarding the development of the proposed approach, we can distinguish the following areas, which allow, on the one hand, to significantly expand the theoretical base of the scientific discipline "theory of modelling the use of resources" (Farkhoutdinov \& Isavnin, 2019), and on the other, to increase the practical significance of the developed methodological approaches:

1. The boundaries expansion of assumptions as a consequence, the development of mathematical models and tools, the practical application of which will increase the competitiveness of Russian engineering enterprises;

2. The study of economic cycles theories and the application of the element of these theories in order to more fully understand the mechanisms of the market and the formation of macroeconomic policy instruments;

3. Strengthening mathematical formalization, including through the use of oscillation theory, with the aim of developing quantitative indicators and their application in the digital economy.

\section{Acknowledgements}

The work is performed according to the Russian Government Program of Competitive Growth of Kazan Federal University.

\section{References}

Baranov, I. A. (2014). Typology of economic cycles and model tools for their research. Russian Journal of Entrepreneurship, 5(251), 20-26.

Boukadi, K., Grati, R., Rekik, M., \& Ben-Abdallah, H. (2019). Business process outsourcing to cloud containers: How to find the optimal deployment?. Future Generation Computer Systems, 97, 397-408. https://doi.org/10.1016/j.future.2019.02.069

Bykova, O. N., Garnov, A. P., Stroev, P. V., \& Pivovarova, O. V. (2019). Employment management policies in single-industry towns in the light of existing issues of precarious employment. International Journal of Economics and Business Administration, 7, 123-134.

Burns, A. F., \& Mitchell, W. C. (1946). Measuring Business Cycles. National Bureu of Economic Reseach.

Errighi, L., Khatiwada, S., \& Bodwell, C. (2016). Business process outsourcing in the Philippines: Challenges for decent work. ILO Asia-Pacific Working Paper Series. 
Farkhoutdinov, I. I., \& Isavnin, A. G. (2019). Theoretical aspects of production forms of sourcing. Journal of Economic Analysis: Theory and Practice, 18(1), 108-120. https://doi.org/10.24891/ea.18.1.108

Gerbl, M., McIvor, R., \& Humphreys, P. (2016). Making the business process outsourcing decision: why distance matters. International Journal of Operations \& Production Management. https://doi.org/10.1108/IJOPM-04-2014-0192

Isavnin, A. G. (2013). Farkhoutdinov II Features of the application of production outsourcing at a Russian automotive enterprise. LAP LAMBERT Academic Publishing, AV Akademikerverlag GmbH \& Co. KG. KG.

Isavnin, A. G., \& Farkhoutdinov, I. I. (2012). A methodological approach to assessing the economic efficiency of the use of industrial outsourcing at an automotive enterprise in Russia. Regional Economics: Theory and Practice, 13(244), 16-21.

Isavnin, A. G., \& Farkhoutdinov, I. I. (2012). The impact of production outsourcing on the breakeven of the enterprise. Financial analytics: problems and solutions, 30(120), 2-8.

Kanniappan, V., \& Selvakumar, J. (2020). Prevalence of Work Related Psychological and Musculoskeletal Problems among Business Process Outsourcing Workers. Journal of Lifestyle Medicine, 10(1), 55. https://doi.org/10.15280/jlm.2020.10.1.55

Kotlyarov, I. D. (2012). The essence of outsourcing as an organizational and economic phenomenon. Competence, 5(96), 28-35.

Krysińska, J., Janaszkiewicz, P., Prys, M., \& Różewski, P. (2018). Knowledge resources development process in business process outsourcing (BPO) organizations. Procedia Computer Science, 126, 1145-1153. https://doi.org/10.1016/j.procs.2018.08.052

Kireeva N., Zavyalov D., Saginova O., Zavyalova N. (2019). Students ' perception of social entrepreneurship. Revista de la Universidad del Zulia, $3^{\mathrm{a}}$ época. Año $10 \mathrm{~N}^{\circ}$ 28. P. 200-210

Lacity, M., Khan, S., \& Carmel, E. (2016). Employing US military families to provide business process outsourcing services: a case study of impact sourcing and reshoring. Communications of the Association for Information Systems, 39(1), 9. https://doi.org/10.17705/1CAIS.03909

Liu, S., Wang, L., \& Huang, W. W. (2017). Effects of process and outcome controls on business process outsourcing performance: Moderating roles of vendor and client capability risks. European Journal of Operational Research, 260(3), 1115-1128. https://doi.org/10.1016/j.ejor.2017.01.020

Mukucha, P., Manyika, T., Madhuku, G., \& Chari, F. (2020). The effects of business process outsourcing on the quality of catering services in tertiary education industry in Zimbabwe. Cogent Business \& Management, 7(1), 1741314. https://doi.org/10.1080/23311975.2020.1741314

Nacer, A. A., Godart, C., Rosinosky, G., Tari, A., \& Youcef, S. (2019). Business process outsourcing to the cloud: Balancing costs with security risks. Computers in industry, 104, 59-74. https://doi.org/10.1016/j.compind.2018.10.003

Orlova, I. A. (2015). Theoretical foundations of the study of economic cyclical. Journal of Economics and Law, 84, 46-49.

Rekik, M., Boukadi, K., \& Ben-Abdallah, H. (2016, June). A comprehensive framework for business process outsourcing to the cloud. In 2016 IEEE International Conference on Services Computing (SCC) (pp. 179-186). IEEE. https://doi.org/10.1109/SCC.2016.30

Rumyantseva, S. Y. (2012). The Peculiarities of modern Phase of Economic Conjuncture. St Petersburg University Journal of Economic Studies (SUJES), 3, 3-19.

Rybina, S. I. (2012). The use of outsourcing to improve the efficiency of the enterprise: foreign experience, Russian practice. Youth and science: Proceedings of the VIII All-Russian scientific and technical conference of students, graduate students and young scientists dedicated to the 155th birthday of K.E. Tsiolkovsky.

Smith, A. P., \& Smith, H. (2017). An international survey of the wellbeing of employees in the business process outsourcing industry. Psychology, 8(1), 160-167. https://doi.org/10.4236/psych.2017.81010

Somjai, S. (2017). Advantages and disadvantages of outsourcing. The Business and Management Review, 9(1), 157-160.

Umukoro, O. E., Eluyela, F. D., Inua, O. I., \& Babajide, S. (2020). Nollywood accounting and financial performance: 
Evidence from Nigerian cinemas. International Journal of Financial Research, 11(2), 271-280. https://doi.org/10.5430/ijfr.v11n2p271

Zandi, G., Chuan, T. K., \& Mansori, S. (2019). A Study of Accounting Outsourcing Decision: The Case of Malaysian SMEs. International Journal of Financial Research, 10(5). https://doi.org/10.5430/ijfr.v10n5p153

Zhang, Y., Liu, S., Tan, J., Jiang, G., \& Zhu, Q. (2018). Effects of risks on the performance of business process outsourcing projects: The moderating roles of knowledge management capabilities. International Journal of Project Management, 36(4), 627-639. https://doi.org/10.1016/j.ijproman.2018.02.002

Zychenko, I. A. (2013). Classifications of theories of economic cycles. Bulletin of Moscow State Regional University, 13-17.

\section{Copyrights}

Copyright for this article is retained by the author(s), with first publication rights granted to the journal.

This is an open-access article distributed under the terms and conditions of the Creative Commons Attribution license (http://creativecommons.org/licenses/by/4.0/). 